\title{
Two Novel Salen Based Chemosensors for Selective Recognition of Zinc(II) Ion
}

\author{
Longchao Du*, Xiaoju Qin, Shixin Huang
}

School of Chemistry and Chemical Engineering \& the Key Laboratory of Environment-friendly Polymer Materials of Anhui Province, Anhui University, Hefei, PRC

*E-mail: dulongchao@sina.com

doi: $10.20964 / 2018.09 .71$

Received: 16 May 2018 / Accepted: 20 June 2018 / Published: 5 August 2018

Two novel salen based chemosensors were synthesized and identified by FT-IR, ${ }^{1} \mathrm{H}-\mathrm{NMR}$ and Elemental analysis. We evaluated the selectivity and sensitivity of probe L1 and L2 toward zinc ions via UV-vis, Cyclic voltammetry and ${ }^{1} \mathrm{H}-\mathrm{NMR}$ measurement. The finding suggested the selective and sensitive recognition toward zinc ions was more typical than the other metal ions. The $\mathrm{Zn}^{2+}$ can be detected well even the concentration of the probes are low to $10 \mu \mathrm{M}$. The stoichiometries of the complexs formed between the probes and $\mathrm{Zn}^{2+}$ are $1: 1$, as determined by Job's method. And these probes showed distinctly different $\mathrm{CV}$ curves with $\mathrm{Zn}^{2+} .{ }^{1} \mathrm{H}-\mathrm{NMR}$ research showed that the hydrogens in $\mathrm{N}=\mathrm{CH}$ - and $\mathrm{OH}$ - are evidently up-field shift. These changes are due to the transform of $\mathrm{N} 2 \mathrm{O} 2$ coordination plane of Schiff bases.

Keywords: Schiff base; Zinc ion; Chemosensor; Recognition

\section{$\underline{\text { FULL TEXT }}$}

(C) 2018 The Authors. Published by ESG (www.electrochemsci.org). This article is an open access article distributed under the terms and conditions of the Creative Commons Attribution license (http://creativecommons.org/licenses/by/4.0/). 